\title{
5
}

\section{Protection through Revisionism?}

\author{
UNHCR, Statistical Reporting, and the Representation \\ of Stateless People
}

\author{
Brad K. Blitz*
}

\section{INTRODUCTION}

One major problem complicating the task of effective humanitarian protection is the lack of quality data on the populations most affected. If protection agencies cannot identify those who need help, then their ambitions of assisting them are unlikely to be realized. This is especially relevant when considering "invisible," hard to reach, or historically marginalized groups for whom we have little baseline data and whose presence is a source of contention for national authorities.

Unfortunately, undercounting is not simply a matter for statisticians and social demographers. It is often a political matter. As Sarfaty writes, "numbers display governmentality because they serve as a technology of power that constitutes populations and makes individuals calculable and therefore governable - both by others and themselves." Who is counted also tells us about governmental and institutional priorities and exposes biases about what counts, and how resources should be allocated. For example, voter registration may not include the total adult citizens because African Americans have been repeatedly denied the right to register to vote in some US states. Official processes may be exploited to discriminate against certain groups and published data may inaccurately reflect population trends.

The rationale for collecting data also reveals political and institutional priorities. National statistical offices play an essential role in governmental planning and are central to the state's claim to legitimacy. Similarly, international organizations, including the United Nations High Commissioner for Refugees (UNHCR), have

\footnotetext{
The author would like to thank the editors, Molly Land, Kathy Libal, and Jillian Chambers, as well as Alessio D'Angelo, Jeff Crisp, Margaret Okole, and Don Kerwin for their helpful advice on earlier versions of this chapter. I am also grateful to Bronwen Manby for her helpful comments on this chapter.

1 G. Sarfaty, "Regulating Through Numbers: A Case Study of Corporate Sustainability Reporting" (2013) 53 Virginia Journal of International Law 575-624 at 588.
} 
turned to the collection of data in the name of enhancing accountability and improving operational delivery. ${ }^{2}$ This includes gathering information to advance target-based agendas, such as the Sustainable Development Goals, and measure progress in meeting institutional priorities. Data collection is a tool of national and global governance. ${ }^{3}$

This chapter presents a critical account of how statelessness has been measured by the UNHCR and its partners. It examines how data have been collected and presented in official reports and joint advocacy initiatives to advance ambitious agendas, including UNHCR's \#IBelong campaign, which seeks to end statelessness by 2024. Although UNHCR is mandated to collect data on people in need of protection, ${ }^{4}$ and has for decades used statistical indicators to map refugee conditions, its focus regarding statelessness has been on measuring accession to international instruments and capturing the percentage of stateless people for whom nationality is granted or confirmed within a given year. While UNHCR has sometimes been accused of inflating refugee numbers, ${ }^{5}$ in this chapter, I argue that UNHCR has actively sought to reduce the number of people counted as stateless. ${ }^{6}$ I suggest that the process of undercounting is indicative of a revisionist turn in humanitarian management characterized by a fixation with narrow definitions and institutional priorities that demand "results," which has been enthusiastically supported by donor states, NGOs, and academics. My central claim is that the ways in which UNHCR data are presented reflect an increasingly top-down logic that ignores the lived experience of stateless people and undermines the provision of humanitarian protection to some who may need it.

The first part of this chapter explores the history of statelessness as a policy area within UNHCR. Developing Reichel's argument of "normative path dependency," I chronicle the evolution of UNHCR's embrace of statistical indicators and the introduction of results-based management approaches to support its Global Strategic Priorities. ${ }^{7}$ I suggest that as the number of refugees appeared to be falling, UNHCR refocused on statelessness, mainstreaming this issue across the institution. The renewed interest in statelessness coincided with UNHCR's shift in favor of results-

$=$ See E. Reichel, "Navigating between Refugee Protection and State Sovereignty: Legitimating the United Nations High Commissioner for Refugees," in K. Dingwerth et al. (eds.), International Organizations under Pressure: Legitimating Global Governance in Challenging Times (Oxford: Oxford University Press, 2019), pp. 195-231.

3 See S. E. Merry, "Human Rights Monitoring and the Question of Indicators," in M. Goodale (ed.), Human Rights at the Crossroads (Oxford: Oxford University Press, 2013), pp. 140-150.

4 Article 35(2) of the 1951 Convention Relating to the Status of Refugees obliges Contracting States to provide the United Nations High Commissioner for Refugees (UNHCR) with statistical data relating to the condition of refugees, the implementation of the Convention, and any laws and decrees relating to refugees upon request.

5 See G. Kibreab, "Pulling the Wool over the Eyes of the Strangers: Refugee Deceit and Trickery in Institutionalized Settings" (2004) 17 Journal of Refugee Studies 1-26.

6 See "About the \#IBelong Campaign to End Statelessness," www.unhcr.org/ibelong/.

7 Reichel, "Navigating between Refugee Protection and State Sovereignty." 
based management tools, employing methodological approaches that put them at a considerable distance from the populations on whose behalf they claimed to be acting. They also set unrealistic targets. And as they worked to systematize their data, they reclassified those who no longer fell in neat categories and amalgamated them into other categories. Noting these failings, I conclude by recommending that rather than making humanitarian protection the servant of legal definitions or pursuing unattainable goals, relief agencies, donor governments, and researchers should recognize the lived experience of stateless people and embrace methodologically robust approaches to identification.

FROM REFUGEES TO STATELESS PERSONS:

INSTITUTIONAL DEVELOPMENTS

Although the term "statelessness" is today treated as a social category in its own right, this is a relatively new trend. Statelessness was long considered a feature of forced displacement, and many of those who today we would describe as stateless were accepted as refugees by receiving states. This was especially true in Europe where the unraveling of the Austro-Hungarian, Russian, and Ottoman Empires gave rise to massive refugee flows. In the late nineteenth and early twentieth century, millions who fled had never enjoyed nationality to begin with, while others saw their nationality status canceled retrospectively or lost upon application for a second nationality, leaving them stateless in the interim.

In the United States, for example, foreign-born men seeking to acquire US nationality were required to file a declaration of intent, at which point they would be forced to renounce any allegiance to another power. Yet they would often wait more than five years before they formally became US citizens, which required a court hearing. As for married women, they were simply assigned their husband's nationality until the Cable Act of $1922 .{ }^{8}$

During the First World War and in the interwar period, states increasingly withdrew nationality to facilitate the expulsion of foreign-born groups. Torpey attributes this to the rise of the surveillance state and the use of immigration controls. ${ }^{9}$ For example, France denationalized foreign-born residents in 1915, three years before the new Soviet and Turkish governments denationalized Russian, Armenian, and Hungarian refugees. In the lead up to the Second World War, Fascist parties introduced racial laws, most famously in Germany (1935), where overnight the Nuremberg Laws divided Germans into "full citizens" and "citizens without political rights."

Following the Second World War, in Europe, stateless individuals and refugees were understood as equivalent and largely interchangeable categories. It is therefore

8 See The Cable Act 1922, ch. 411, 42 Stat. 1021 (also known as the "Married Women's Independent Nationality Act").

9 J. Torpey, The Invention of the Passport: Surveillance, Citizenship, and the State (Cambridge: Cambridge University Press, 2000). 
not surprising, given the expressly European context informing the design of the 1951 Convention on the Status of Refugees, that millions of stateless people saw their protection needs subsumed under the refugee regime. Although a new instrument was introduced specifically for stateless people, namely, the 1954 Convention Relating to the Status of Stateless Persons, few states were party to it. Moreover, the Convention itself established a narrow definition of statelessness. Under Article 1, it defined a "stateless person" as a person "who is not considered as a national by any State under the operation of its law." ${ }^{\prime \prime}$ This definition is used to describe those who are de jure stateless, in contrast to the vast majority of those who are de facto stateless or effectively stateless, that is, individuals who cannot obtain proof of their nationality, residency, or other means of qualifying for citizenship and are thus practically excluded from protection by the state. ${ }^{\text {"1 }}$

The 1954 Statelessness Convention was initially conceived as a protocol to be included as an addendum to the 1951 Refugee Convention. Both were developed from the premise that refugeehood and statelessness were temporary statuses and that states would eventually integrate the millions of people who fell within these categories. A second Convention on the Reduction of Statelessness was introduced in 1961 with provisions to disallow statelessness at birth and to avoid statelessness resulting from the loss, deprivation, or renunciation of nationality in later life, as well as statelessness resulting from state succession. Yet, this instrument also presented several limitations: most importantly, it defers to states and asserts that nationality shall be granted by "operation of law to a person born in the State's territory," where such persons would "otherwise be stateless." ${ }^{\text {"2 }}$ One important failing of this convention is that it does not prohibit the possibility of revocation of nationality, nor does it retroactively grant citizenship to all currently stateless persons; hence, it only offers a partial remedy to the problem of statelessness.

Further geopolitical divisions during the Cold War, which largely prevented refugees from leaving the Soviet bloc, undermined any moves to establish an effective regime for stateless persons during that period. In the meantime, Palestinians, who were arguably among the most visible stateless groups, were also treated separately. Even though the ${ }_{1961}$ Statelessness Convention provided for an international body that would serve to examine and assist individual claims, ${ }^{13}$ the UN system was hampered by geopolitical and organizational tensions. In 1974, when the 1961 Statelessness Convention came into effect, UNHCR did not have the capacity to fulfill this role. Not only was the agency distracted by the surge in

10 United Nations Convention Relating to the Status of Stateless Persons, September 28, 1954, 360 U.N.T.S. 117 .

${ }^{11}$ The final act of the Convention includes a nonbinding recommendation that states should "consider sympathetically" the possibility of according de facto stateless persons the treatment that the Convention offers to de jure stateless people. For a historical overview, see C. A. Batchelor, "Stateless Persons: Some Gaps in International Protection" (1995) 7 International Journal of Refugee Law 232-259.

${ }_{12}$ Convention on the Reduction of Statelessness, August 28, 1961, 989 U.N.T.S. 175.

13 Ibid. 
refugees, especially in Asia, Latin America, and Africa, but until 2003, it was also operating under a temporary mandate renewable every five years.

Over the past fifteen years, UNHCR has sought to bring statelessness more prominently within its remit. ${ }^{14}$ A background paper prepared by Hugh Massey in 2010 to identify UNHCR's responsibilities and set out the basis for more consistent operational definitions states that UNHCR "tended to assume that it had a mandate for de facto stateless persons who are not refugees just as much as it has a mandate for de jure stateless persons who are not refugees." ${ }^{15}$ UNHCR now operates a statelessness unit that supports a range of field activities and, since 2006, has required its country offices to include stateless people in their reports. It has published papers on statelessness; ${ }^{16}$ has assisted many countries with surveys, registration campaigns, and population censuses; and has also provided technical advice.

As the number of recognized refugees stabilized and then started to fall in the twenty-first century, interest in the phenomenon of statelessness rose, and UNHCR emerged as the most vocal advocate on this issue. One core responsibility of UNHCR is to promote legal reform to address gaps in nationality and related legislation, including pressing states to accede to the Statelessness Conventions. UNHCR points to some achievements here, recording that in 2020 some twelve countries took steps to remove gender discrimination from their nationality laws and forty-nine states acceded to the two conventions on statelessness. ${ }^{17}$ In 2009, UNHCR published a policy paper to inform statelessness determination procedures and provide a mechanism for analyzing situations where persons are stateless or are at risk of becoming stateless. ${ }^{18}$ It has since published handbooks and operational guides. UNHCR now routinely provides reports and recommendations for the Universal Periodic Review on the topic and covers statelessness in its Global Appeals and Global Reports. It has also published educational tools ${ }^{19}$ and includes statelessness in its flagship report, The State of the World's Refugees. ${ }^{20}$

${ }^{14}$ See Conclusion on Identification, Prevention and Reduction of Statelessness and Protection of Stateless Persons No. 106, UNHCR ExCom., U.N. Doc. A/AC.96/1035 (October 6, 2006).

15 UNHCR and De Facto Statelessness, Hugh Massey, LPPR/2010/o1 (April 2010), www.refworld .org/docid/4bbf $387 \mathrm{~d} 2 . \mathrm{html}$, p. ii.

${ }^{16}$ See UNHCR, Guidelines on Statelessness No. 3: The Status of Stateless Persons at the National Level, HCR/GS/12/03 (July 17, 2012), www.refworld.org/docid/5005520f2.html.

17 See "How UNHCR Helps Stateless People," www.unhcr.org/uk/how-unhcr-helps-statelesspeople.html.

18 UNHCR, "Statelessness: An Analytical Framework for Prevention, Reduction, and Protection," Global Report 2018 (2019), www.refworld.org/docid/49az8afb2.html.

19 UNHCR, A Guide to Teaching on Statelessness (September 2010), www.refworld.org/docid/ 4d $7 f_{5} f_{9} 82 . h$ tml; UNHCR, Self-Study Module on Statelessness (October 1, 2012), www.refworld .org/docid/5ob8996oz.html.

20 UNHCR, The State of the World's Refugees: In Search of Solidarity (2012), www.refworld.org/ docid/510ofec $32 . h$ tml. 
As the profile of statelessness within UNHCR increased, so too did budgets. There was a marked upturn in 2010 when UNHCR allocated US \$38.5 million for its statelessness operations - approximately three times the expenditure on such activities just one year earlier. ${ }^{21}$ Expenditure on this head has continued to rise. For 2021, $\$ 81.6$ million has been allocated to UNHCR's statelessness program - 1 percent of the agency's overall budget. ${ }^{22}$

Accompanying this expansion has been a greater emphasis on targets. In the mid1990s, on the heels of the Srebrenica massacre and genocide in Rwanda, the UNHCR was struck by several scandals that forced donors to question its accountability and effectiveness at supporting those in need of humanitarian protection. Since then, the UNHCR, like other humanitarian agencies, has worked to develop more coherent systems of accountability and has strived to recast its image to donors. To this end, it has enthusiastically embraced the use of standards and indicators. Most notably, the UNHCR was a founding member of the 1997 Sphere Project, which set out minimum standards to improve the quality of humanitarian responses. In 2002, UNHCR launched the "Standards and Indicators Initiative" to firm up assessment, planning, and implementation within the agency. The collection and presentation of statistical data was seen as promoting efficiency and measuring the effectiveness of projects in order to satisfy donors and other stakeholders. It also gave the impression of greater accountability, though as Dunlop argues, internally generated indicators may be less than objective and raise questions about who is collecting data, for whom, and who shapes the ways in which findings are presented.

Regardless of whether the resulting data is released publicly or used internally to determine the effectiveness of programs, there may be incentives for collection officers to downplay or couch certain failures if they are perceived to reflect poorly on sectoral management. ${ }^{23}$

In 2004, UNHCR published a Practical Guide to the Systematic Use of Standards and Indicators in UNHCR Operations, which was followed by a comprehensive management and structural reform process two years later. ${ }^{24}$

Although the reform process was sparked by external events that had exposed the agency's failures, Reichel contends that internal factors, including a new institutional culture based on the need to show improvement for its legitimacy, set the

${ }^{21}$ See UNHCR, "Addressing Statelessness," UNHCR Global Appeal 2010-11 (2010), www.unhcr .org/4bo2c5e39.pdf, p. 42.

${ }_{22}$ See UNHCR Executive Committee, Update on Budgets and Funding (2019, 2020-2021), U.N. Doc. EC/71/SC/CRP.6 (February 20, 2020), www.unhcr.org/5e6azc497.pdf.

23 E. Dunlop, Indications of Progress? Assessing the Use of Indicators in UNHCR Operations (UNHCR, July 2011), www.refworld.org/docid/4e 55ec4e2.html.

${ }^{24}$ See UNHCR Policy Development and Evaluation Service (PDES), Measure for Measure: A Field-Based Snapshot of the Implementation of Results-Based Management in UNHCR, U.N. Doc. PDES/2010/13 (November 2010), www.unhcr.org/4cf3ad8f9.pdf. 
UNHCR on a managerialist path. She argues that a process of "discursive entrapment" accompanied by an "intellectual climate in which 'new public management' norms had gained clout, were equally relevant to determine the pace and course of the rise of managerial norms." 25

Over the past fifteen years, UNHCR has moved to rely on a sophisticated resultsbased management approach in the planning, implementation, and assessment of its activities. ${ }^{26}$ The approach, championed by the UN Development Group (UNDG), ${ }^{27}$ now features in UNHCR's Results Framework, a log-frame-based tool that includes scores of indicators. This top-down orientation requires, for example, the introduction of "precise" and measurable criteria and "evidence of change." 28 Evaluations of UNHCR operations have repeatedly relied on such criteria. ${ }^{29}$

Statelessness features within UNHCR's Global Strategic Priorities, which include a range of legal and humanitarian objectives. Key measures are described as "impact indicators" and "engagement" and include: reforming of law and policy consistent with international standards on the prevention of statelessness, principally through accession to the two UN statelessness conventions, and achieving annual targets of individuals who will acquire nationality or have it confirmed. ${ }^{30}$

Although the results-based approach has made important contributions to UNHCR's work in its emphasis on transparency and benefits for budgetary planning in particular, ${ }^{31}$ the new ways of measuring impact have shifted it away from the needs of the most vulnerable. Reichel goes so far as to suggest that the new managerialism has created a tension within the organization over its priorities to advance its humanitarian mission and the reality that it is increasingly beholden to states. ${ }^{32}$ Arguably, the results-based approach has encouraged certain reductive practices, the effects of which have not been fully explored. In the case of statelessness, the imperative to present results, together with a narrow definition of who counts as stateless, has led the UNHCR to privilege certain statistical data sources over other information and in effect to round down a problem that they could not possibly estimate. The next section describes both of these shifts.

${ }_{25}$ Reichel, "Navigating between Refugee Protection and State Sovereignty," p. 229.

26 Ibid.

${ }^{27}$ See UNDP, Results-Based Management Handbook (2011), www.ilo.org/public/english/bureau/ program/dwcp/download/undg_rbmion1.pdf.

${ }_{28}$ See UNHCR, Practical Guide to the Systematic Use of Standards \& Indicators in UNHCR Operations (2006), www.unhcr.org/uk/statistics/unhcrstats/40eaag804/practical-guide-systemat ic-use-standards-indicators-unhcr-operations.html.

29 See, e.g., Oxford Policy Management, Evaluation of UNHCR's Implementation of Three of Its Protection Strategies: The Global Education Strategy, the Updated SGBV Strategy, and the Child Protection Framework (July 2017), www.unhcr.org/5a183dgc7.pdf.

$3^{\circ}$ UNDP, Results-Based Management Handbook, p. 10.

${ }^{31}$ See PDES, Measure for Measure.

$3^{2}$ Reichel, "Navigating between Refugee Protection and State Sovereignty." 


\section{UNHCR'S DATA ON STATELESS PEOPLE}

The UNHCR currently reports that it has "data" on some 4,161,980 stateless people but admits that "the true global figure is estimated to be significantly higher." 33 It has also recently recognized limitations with its method of calculation:

However, this [global] figure is not based on robust or transparent demographic methods and, as a result, its use to track progress on reducing statelessness and for policy, programming, or advocacy purposes is limited .... [M]ore is required to capacitate member states and coordinate data collection to estimate the number of stateless persons within their territory. ${ }^{34}$

Nonetheless, it claims to have reliable data for seventy-eight countries. These aforementioned claims warrant further examination.

\section{Who Is Stateless? And Where Do They Live?}

Until 2019, it was unclear if UNHCR's data only referred to de jure stateless people, those described as falling under their mandate, or if they also captured de facto stateless individuals and persons with indeterminate nationality. ${ }^{35}$ While the term "de facto" no longer features prominently in UNHCR documents, UNHCR's website states that the agency is now considering both de jure stateless people and those with indeterminate nationality. ${ }^{36}$ In its 2020 report to UNHCR Standing Committee, which reviews UNHCR's activities and programs, the agency recorded that it used mixed data types to estimate figures of stateless people but did not elaborate: "[The table] [r] efers to persons who are not considered as nationals by any State under the operation of its law .... but data from some countries may also include persons with undetermined nationality." 37

Second, UNHCR's approach to working with data on those of "indeterminate nationality" introduces other practical considerations, including the presumption that states will provide accurate and impartial information and are prepared to recognize links to other countries. "UNHCR uses the working definition of a person who lacks proof of possession of any nationality and who at the same time has or is perceived as having links to a State other than the one he/she is living in." ${ }^{8}$ Not only does this approach defer to states' cooperation, but it also discounts the possibility

33 See UNHCR, Global Trends: Forced Displacement in 2018, www.unhcr.org/5do8d7ee7.pdf, p. 51.

34 L. Chen et al., UNHCR Statistical Reporting on Statelessness (October 2019), www.unhcr.org/ statistics/unhcrstats/5dge182e 7/unhcr-statistical-reporting-statelessness.html.

35 UNHCR Executive Committee, Update on Budgets and Funding (2019, 2020-2021), p. 27.

${ }^{6}$ See UNHCR, "Refugee Data Finder - Methodology," www.unhcr.org/refugee-statistics/meth odology/.

37 UNHCR Executive Committee, Update on Budgets and Funding (2019, 2020-2021).

$3^{8}$ Ibid. 
that states may misuse data and personal information. ${ }^{39}$ As noted elsewhere, there is a long history of states' culpability in the creation of stateless people..$^{\circ}$

Third, while recognizing that "a formal definition of a person with undetermined nationality does not exist," UNHCR has changed its terms of measurement from one year to another: "UNHCR previously also reported on de facto stateless populations but discontinued doing so in mid-2019 based on an assessment that de facto statelessness was often incorrectly used to refer to people who meet the statelessness definition in the 1954 Convention and who should, therefore, be reported as such." ${ }^{\prime 1}$ This inconsistency makes longitudinal and comparative analysis especially problematic.

Fourth, the presentation of figures raises additional queries about coverage. As the Center for Migration Studies (CMS) found in their 2020 study of statelessness in the United States, the net used by UNHCR misses a large number of people who are stateless or potentially at risk of statelessness. Rather, drawing upon different datasets, including the American Community Survey (ACS) data, they maintain that the population of stateless people is both more diverse and significantly larger than UNHCR assumes..$^{42}$ There is also a lack of published statistics for countries that have experienced major refugee flows and that have historically hosted stateless groups. Most importantly, there are no data for large refugee-hosting states and countries that have significant internal migration, such as Pakistan, South Africa, and Uganda. There is no information on other countries that previously were reported to have stateless populations such as Nepal, where the US government reported that an estimated six million individuals lacked citizenship documentation. ${ }^{43}$ There are even gaps in reporting on states that have introduced statelessness determination procedures; there should be some reliable information, for example, for Switzerland. In other cases, these figures are bizarrely low. ${ }^{44}$ For example, Egypt, a country with a population of more than 100 million, which has been home to

39 See Economic Commission For Europe, Difficult To Measure Census Topics: Measuring Statelessness through Population Census, Conference of European Statisticians, U.N. Doc. ECE/CES/AC.6/2008/SP/5 (May 13, 2008), https://unstats.un.org/unsd/censuskbzo/Attachm ents/2008UNHCR_ECE-GUIDe59366dbdf874942bae645a8b8319128.pdf, p. 4.

$4^{\circ}$ See B. K. Blitz and M. Lynch (eds.), Statelessness and Citizenship: A Comparative Study on the Benefits of Nationality (Cheltenham, UK: Edward Elgar Publishing, 2011).

$4^{11}$ Ibid.

$4^{2}$ The CMS authors argue that some 218,000 people are at risk of statelessness in the United States. See D. Kerwin, D. Alulema, M. Nicholson, and R. Warren, "Statelessness in the United States: A Study to Estimate and Profile the US Stateless Population" (2020) 8(2) Journal on Migration and Human Security 150-213.

43 U.S. Department of State, 2019 Country Reports on Human Rights Practices: Nepal, Bureau of Democracy, Human Rights, and Labor (2020), www.state.gov/reports/2019-country-reports-onhuman-rights-practices/nepal/.

44 The UNHCR tool, the "Refugee Data Finder," www.unhcr.org/refugee-statistics/download/? $\mathrm{url}=\mathrm{U}_{3} \mathrm{cg}$, provides "information on displaced and stateless populations, including their demographics. The database also reflects the different types of solutions for displaced populations." 
more than 200,000 refugees, including generations of Palestinians, records having just five stateless people. ${ }^{45}$

\section{Redefining Statelessness and Developing Data}

With refugee numbers falling, UNHCR commissioned many studies on statelessness in which it prioritized de jure statelessness over other statuses:

In practice, it may sometimes be difficult to distinguish between de jure and de facto statelessness. Because of these complexities, UNHCR would also recommend that censuses ordinarily be restricted to gathering information only about de jure stateless populations, and populations with undetermined nationality. ${ }^{46}$

In addition to the methodological challenges noted here, Massey's historical interpretation of the diplomatic discussions during the drafting of the 1954 Statelessness Convention led him to argue for a narrow definition that focused on de jure statelessness. ${ }^{47}$ Massey calls attention to the Final Act of the ${ }_{1951}$ Conference of Plenipotentiaries on the Status of Stateless Persons, which recommended limiting the scope of protection to only those "who have renounced that protection and whose reasons for doing so are considered valid by the foreign State." ${ }^{8}$ Thus, the matter turns on state recognition of the individual's statelessness status. Massey then suggests that many of the areas one might consider to fall under the banner of de facto statelessness might be better covered under the Refugee Convention. ${ }^{49}$ Furthermore, he notes that, as with refugee matters, the presumption is on the individual to demonstrate that they no longer have protection from their country of origin:

As a rule, there should have been a request for, and a refusal of, protection before it can be established that a given nationality is ineffective. For example, Country A may make a finding that a particular individual is a national of Country $\mathrm{B}$, and may seek to return that individual to Country $\mathrm{B}$. Whether or not the individual is de facto stateless may depend on whether or not Country B is willing to cooperate in the process of identifying the individual's nationality and/or to permit his or her return. ${ }^{\circ}$

Based in part on Massey's paper, UNHCR developed a handbook to "advise on the modalities of creating statelessness determination procedures, including questions of evidence that arise in such mechanisms." ${ }^{1}$ The handbook limited the recognition

45 Ibid.

${ }^{6}$ Economic Commission for Europe, Difficult to Measure Census Topics, pp. 2-3.

47 UNHCR, UNHCR and De Facto Statelessness, p. 27.

$4^{8}$ Ibid., p. 18.

49 Ibid., p. 30.

50 Ibid., p. 74 .

${ }^{51}$ UNHCR, Handbook on Protection of Stateless Persons (2014), www.refworld.org/pdfid/53b67 6aa4.pdf, p. 6. 
of stateless persons to the definition in the 1954 Convention and focused on the obligations of States that are party to the Convention - again, the plight of de facto stateless persons was pushed to the margins. One consequence of UNHCR's advice in the handbook was that the authors of UNHCR-commissioned mapping studies did not try to estimate the number of that country's (i.e., the selected country included in the mapping studies) stateless population. ${ }^{52}$

One further dilemma, which arguably applies to all international agencies whose mandate relies on the implementation of international law, is the overt bias toward states - a tendency bolstered by the technocratic logic that further informed the work of UNHCR. Like other UN agencies that must present "results" to donors, over the past fifteen years UNHCR has been building up its statistical capacity, including most recently by establishing a joint data center with the World Bank. ${ }^{53}$ In the 2005 Statistical Yearbook (published in 2007), for the first time the Agency set out its rationale for providing better statistical coverage: "In an effort to ensure evidencebased resource allocation and policy formulation, a variety of information sources are utilized to quantify and profile UNHCR's population of concern." 54 This ambition was reflected in its increased coverage of groups that had been underreported. For example, while UNHCR's coverage of stateless people included just thirty states in 2004, by 2015 , UNHCR was publishing data on seventy-nine states. ${ }^{55}$

Most important, UNHCR also started to explain its methodological processes for estimating people who fell under its mandate and then, like other agencies, sought to make its data more operational..$^{56}$ It offered more comprehensive definitions of the indicators used, the various categories of concern, and its main sources of data. In its notes to the published statistics, UNHCR provides some important small print. In the 2011 Global Appeal, UNHCR recorded that "the data are generally provided by governments, based on their own definitions and methods of data collection." 57 This statement was repeated to UNHCR's donors as recently as February 2020.58 A close reading of the footnotes in UNHCR's principal publications records the methodological difficulties involved in data estimation and the challenges facing UNHCR and member states. For example, its 2020 report on its financial performance lists the different approaches it has taken to produce data, which include relying on national estimates, excluding data, and adjusting based on censuses and

$5^{2}$ Kerwin et al., "Statelessness in the United States."

53 See Strategic Advisory Council, Strategy for the Joint Data Center on Forced Displacement 2021-2023: Zero Draft (August 27, 2020), www.jointdatacenter.org/wp-content/uploads/202o/o8/ JDC-strategy_zero-draft_August-2020.pdf.

54 UNHCR, UNHCR Statistical Yearbook 2005 (Geneva: UNHCR, 2007), p. 19.

55 See UNHCR, 2004 UNHCR Statistical Yearbook (Geneva: UNHCR, 2005); UNHCR, UNHCR Statistical Yearbook 2015 (Geneva: UNCHR, 2017).

$5^{6}$ See UNHCR, Guidance Document on Measuring Stateless Populations (May 2011), www .refworld.org/docid/4f6887672.html.

57 UNHCR, Global Appeal 2010-11.

$5^{8}$ UNHCR Executive Committee, Update on Budgets and Funding (2019, 2020-2021), p. 30. 
registers. In some cases, the information provided by national governments reflects a considered approach to estimation:

The statelessness figure is based on a Government estimate of individuals who ... migrated to Côte d'Ivoire ... and who did not establish their nationality at independence or before the nationality law changed in 1972 . The estimate is derived in part from cases denied voter registration in 2010 because electoral authorities could not determine their nationality at the time .... The estimate does not include individuals of unknown parentage who were abandoned as children and who are not considered as nationals under Ivorian law. ${ }^{59}$

UNHCR also presented information in more user-friendly formats. Today, UNHCR's website includes a versatile data builder that allows users to select variables and indicators in order to construct detailed tables using composite data from UNHCR's operational and statistical activities, national sources, and other UN agencies and partners.

Amid claims of greater accuracy, UNHCR explicitly privileged certain types and sources of data. ${ }^{6 \circ}$ Above all, it considered national censuses and population registers most useful, as Massey recommends:

For such country-related information to be treated as accurate, it needs to be obtained from reliable and unbiased sources, preferably more than one. Thus, information sourced from State bodies directly involved in nationality mechanisms in the relevant State, or non-State actors which have built up expertise in monitoring or reviewing such matters, is preferred. ${ }^{61}$

There are several problems with this statement. First, it presumes that national censuses accurately record the status of individuals surveyed when, in practice, national censuses rely on self-completed questionnaires. ${ }^{62}$ Moreover, some states do not have a central population registry. ${ }^{63}$ Second, it fails to recognize how bias applies to all forms of data, including official information produced by state bodies. Third, it assumes that individuals have sufficient agency to obtain status and, equally important, that states will cooperate to recognize such claims. These challenges were acknowledged by the Conference of European Statisticians more than twelve years ago.

59 Ibid., p. 31.

60 The main sources include (1) UNHCR's statistical activities, which collate data from national sources and some UNHCR operations; (2) United Nations Relief and Works Agency for Palestine Refugees in the Near East (UNRWA), which provides information limited to registered Palestine refugees under UNRWA's mandate; (3) data provided by the Internal Displacement Monitoring Centre (IDMC), limited to people displaced within their country due to conflict or violence.

61 UNHCR, Handbook on Protection of Stateless Persons, p. 33.

${ }^{6}$ Economic Commission for Europe, Difficult to Measure Census Topics, p. 5.

63 See Kerwin et al., "Statelessness in the United States." 
Moreover, in many countries, stateless persons live precariously on the margins of society because they lack identity documents, are illegally in the territory, or are subject to discrimination. They therefore may be reluctant to come forward to be counted, or to reveal their personal circumstances, because of concerns that such information may be used against them. Indeed, history shows that population data has even been misused in certain countries in the past to render certain groups stateless through denationalization. ${ }^{64}$ Unfortunately, contrary to UNHCR's assumptions, testimonies of stateless people record that states have repeatedly dismissed these criticisms.

Here are two cases from the United Kingdom, a country that, both before and after the introduction of statelessness determination procedures, has proven reluctant to allow some long-standing citizenship claims deriving originally from the colonial period. There are six different classes of British nationality, offering more or fewer civil and political rights. In 1948, the United Kingdom introduced a new law to address its evolution from an imperial system to a commonwealth of independent states. The Commonwealth Heads of Government agreed that each member would adopt their own national citizenship, while the status of "British subject" would continue, as a supranational category. ${ }^{65}$

On January 1, 1949, the United Kingdom established the status of Citizen of the United Kingdom and Colonies (CUKC). Until the early 196os, there was little difference in UK law between the rights of CUKCs and other British subjects, all of whom enjoyed the right to enter and remain in the United Kingdom for work or family life. However, in many parts of the Commonwealth, newly independent colonies introduced nationality provisions that withdrew CUKC status, unless the person had a connection to the United Kingdom or a remaining colony (e.g., through birth in the United Kingdom). There were some important exceptions. For example, CUKC status was not withdrawn from the Crown colonies of Penang and Malacca that were integrated into the Federation of Malaysia in 1957. Hence, hundreds of thousands continued to enjoy the dual status of CUKC and citizen of Malaysia.

Over the following fifty years, the UK government legislation reduced the rights of former imperial subjects and established a multitiered approach to UK citizenship, which over time disadvantaged those born outside the British Isles and gradually restricted the rights to enter, work, and settle in the United Kingdom to a minority of former subjects. Specifically, the 1971 Immigration Act introduced the concept of patriality, by which only British subjects with sufficiently strong links to the British Isles (e.g., being born in the islands or having a parent or a grandparent who was

64 Ibid.

65 The meaning of "British subject" changed radically in 1948. All those who were British subjects became CUKCs (Citizens of the United Kingdom and Colonies) in 1948; and the classification of British subject was then demoted to become an umbrella term used for everyone who had some sort of UK connection. 
born there) had right of abode. The 1981 British Nationality Act further reduced the rights of former British subjects. Commonwealth nationals now enjoyed one of six categories of British nationality: British citizens, British Overseas Territories citizens, British Overseas citizens, British Nationals (Overseas), British subjects, and British protected persons. Today, only British citizens and certain Commonwealth citizens have the automatic right of abode in the United Kingdom.

Until the Windrush scandal of $2018,{ }^{66}$ when dozens of former British subjects who had arrived before 1973 were wrongly detained and deported to Caribbean countries, the controversies regarding British nationality statuses attracted little public attention. It was inconceivable that former British subjects, including those with the status of CUKC, might suffer from the loss of nationality on UK soil. Rather, statelessness was considered a distant and understudied problem, more applicable to the former colonies in the Global South. A handful of legal cases and press reporting on crimes involving nationals from former British colonies, however, served as a reminder that individuals present on UK territory might also be caught between nationality statuses. One notable case involved a group of individuals who were unable to rely on the UK government to determine their status.

In the summer of 2004, police and immigration officers arrested some refugee families in Oxford as part of "Operation Iowa." ${ }^{167}$ The incident led to a criminal trial and inquiry that resulted in the cancellation of refugee status and withdrawal of state protection from the families, including the children. What complicated the matter was that the families concerned claimed not to be Pakistani, as reported, but from the disputed region of Kashmir, administered by India since 1954 .

Even though the United Kingdom has extensive official channels to the governments of India and Pakistan, all three states refused to rule on the status of the families. The nationality struggles facing Kashmiris are well documented. Those affected include more than 100,000 Punjabi refugees who fled to Jammu and Kashmir from neighboring Sialkot (now in Pakistan) in 1947, and whose descendants have been denied Indian citizenship ever since.

The refugees who settled in Oxford claimed to be from Kashmir, although they had ties to Pakistan and their ancestral home was described as "Sialkot." Their specific nationality status was brought to light when they were taken to court, where their rights to remain in the United Kingdom were called into question. In the 2005 criminal case, R v. Faruq and Others ${ }^{68}$ (Operation Iowa), the Crown Prosecution Service claimed that there had been a conspiracy to contravene the Immigration Act by bringing relatives into the United Kingdom under bogus pretenses and then falsely claiming asylum (on the grounds they were persecuted

66 The name referred to the Empire Windrush, the ship that brought one of the first groups of West Indian migrants to the United Kingdom in 1948 .

${ }^{6}$ See C. Sawyer and B. K. Blitz (eds.), Statelessness in the European Union: Displaced, Undocumented, Unwanted (Cambridge: Cambridge University Press, 2011).

${ }^{68}$ R v. Faruq and Others (Operation Iowa) (2005) (unreported). 
in India as Kashmiri) as a prelude to falsely claiming benefits from government departments and local authorities. The Home Office revoked the status of several of the parties concerned, including the children of the families involved. It was argued that if the families had lied during their asylum application, then other information could no longer be considered credible, including the ages of some of the children. For more than a decade, the Kashmiri children lived without status, turning to charitable organizations and the goodwill of professionals to get by.

The story of Liew Teong Teh, a resident of the United Kingdom since 2001, presents a contrasting case where a law-abiding British Overseas Citizen (BOC) was rendered stateless, while the UK government proved unwilling to correct his status. Teh was born a BOC and citizen of Malaysia. After completing an MSc in Engineering at the University of Wolverhampton, he applied for indefinite leave to remain in 2005, under the impression he would be eligible for British citizenship based on his status. Following the advice of his lawyers, he renounced his Malaysian citizenship in 2006 and applied for leave to remain in the United Kingdom. In so doing, he became stateless. He recalls:

I was shocked to discover that the legal advice I had been given was misleading and that renouncing my Malaysian citizenship violated the Home Office's Asylum and Immigration tribunal's own rules .... Even though I have proof that I was misled and given the wrong advice on relinquishing my Malaysian citizenship, neither the Malaysian High Commission or the Home Office will accept me as a citizen. ${ }^{69}$

Teh then applied for permission to remain in the United Kingdom as a stateless person under Part 14 of the Immigration Rules. He asked the Malaysian authorities to confirm that he had successfully renounced his citizenship of Malaysia, which they did in 2009. However, on two occasions, the Home Office refused his request and he was liable for removal. In 2013, the Home Office issued guidance relating to the removal of certain classes of British passport holders: ${ }^{70}$

Removing British Protected person, BOTC, BNO, and BOC passport holders[:] Passport holders may be served with notice of illegal entry but removal is not straightforward. The person concerned must apply for entry clearance to the appropriate Embassy or High Commission of the country to which he is to be removed. If entry clearance is issued, he may then be removed. If the Embassy or High Commission refuse the application and he can prove this by presenting a letter from them, leave to remain in the UK may be granted by Temporary Migration if further efforts to obtain re-admission to his country of origin are unlikely to prove successful..$^{71}$

69 J. Andersson, "Man Stuck in Limbo after Being Left Stateless for 15 Years," inews (July 22, 2020), https://inews.co.uk/news/man-limbo-stateless-15-years-home-office-mistake-558555.

${ }^{70}$ See Home Office, "Immigration Enforcement General Instructions" (December 10, 2013), https://assets.publishing.service.gov.uk/government/uploads/system/uploads/attachment_data/ file $/ 270023 /$ chapter 48 .pdf\#page $=7$.

${ }^{71}$ Ibid., p. 8. 
The Home Office also issued specific guidance in the case of BOCs who were formerly citizens of Malaysia, like Teh, noting that the UK government was working with the Malaysian authorities to devise a scheme whereby they can be returned to Malaysia and reestablish Malaysian nationality from within Malaysia. ${ }^{72}$

One positive outcome from the discussions between the UK government and Malaysia was the decision to suspend removals, ${ }^{73}$ even though it did nothing to advance Teh's request for nationality, which in turn would ground his right to remain in the United Kingdom permanently. After further refusals by the Home Office to recognize his status, Teh then sought to press the High Court for a judicial review of the Home Office's decision, and his petition was refused in 2017 in part because the UK government contested Teh's status as a stateless person because he holds British Overseas citizenship and is admissible to Malaysia. ${ }^{74}$

As of September 2020, Teh is no longer considered a national by Malaysia, nor of the United Kingdom, and remains in limbo. Teh's case bears many similarities to the plight of the Oxford-based Kashmiri families, where neither India nor Pakistan was prepared to address their claims. In their case, we see how historical antagonism between neighboring states can undermine the prospect of collaboration in determining "ineffective nationality," as Massey proposes.

These examples are far from exceptional. Across the globe, there are many ways in which states may obstruct individuals from securing recognition of their claims or affirming their status. Even more glaring is how some states have conspired to keep people in precarious situations. Thus, minorities in Assam are currently facing the threat of exclusion from the all-India National Register of Citizens. Although the government claims to be updating the register to prevent immigrants from Bangladesh settling in India, millions of long-term-settled residents have been caught up in this exercise in retrospective immigration control. When a draft register was released in 2018, an estimated 4.1 million people were left off the list. Although this number has come down to approximately two million, many remain at risk of statelessness since local authorities refuse to accept official documents such as school leaving certificates (known as migration certificates) as evidence of status. ${ }^{75}$

These case studies also challenge other methodological assumptions that underlie UNHCR's results framework, above all the belief that some of its indicators accurately reflect the outcomes they seek to measure. As Teh's case shows, the United Kingdom's accession to both UN statelessness conventions and its introduction of statelessness determination procedures does not mean that the United Kingdom has

\footnotetext{
$7^{2}$ Ibid.

73 Ibid.

74 Teh v. Secretary of State for the Home Department, [2018] EWHC 1586 (Admin) (June 22, 2018).

75 For a comprehensive list of those categories of people who qualify to be registered, see "What Is NRC? Here Is What You Need to Know," India Today (June 20, 2019), www.indiatoday.in/ information/story/what-is-nrc-here-is-what-you-need-to-know-1552817-2019-o6-2o.
} 
resolved situations of statelessness. Rather, Teh's case demonstrates that legal reform - UNHCR's go-to solution - may not be sufficient.

\section{COUNTING AND MISCOUNTING STATELESS PEOPLE}

Within UNHCR, statistical reporting now focused on de jure statelessness, as recorded in the 2015 Statistical Yearbook. ${ }^{76}$ No longer did UNHCR speak of de facto statelessness and those with indeterminate nationality. The figures presented, however, raised many questions about the methodologies used and the veracity of their sources. Until 2017, UNHCR's formal position was that there were an estimated ten million stateless people in the world. ${ }^{77}$ This number had come down from twelve million over the previous five years, with little explanation. Even though UNHCR recognized that its estimates were provisional, it continued to rely on them, amalgamating data sources and rough estimates.

In addition to their program of identifying and estimating the global population of stateless people, ${ }^{78}$ the logic of reporting, of focusing on more closely defined categories of stateless groups, and the wider mandate that seeks to reduce and prevent statelessness, gave rise to a new ambition: UNHCR was to end statelessness.

\section{The Politicization of Data}

With glossy photographs reminiscent of Benetton adverts, UNHCR launched a 2014 campaign, \#IBelong, to end statelessness within a decade - this, although its reporting on statelessness was still a work in progress, and it did not have reliable baseline data on the scale of the problem. Benetton eventually appeared as UNHCR's formal partner, with its logo at the foot of UNHCR's website. UNHCR also set unrealistic targets, including the collection of ten million signatures from the public in support of ten actions deemed essential to end statelessness. ${ }^{79}$ By August 2020, the \#IBelong campaign had secured 98,296 signatures - just under one percent of its target - and was attracting fewer than twenty-five signatures a month. ${ }^{8 \circ}$

UNHCR published quarterly updates on the \#IBelong campaign but, to date, there has been no independent assessment, no performance or output based evaluations, and no recognition that UNHCR and its partners are failing to meet their targets. Instead, UNHCR has called attention to the many recent pledges made by member states that include introducing statelessness determination procedures,

${ }^{76}$ UNHCR, UNHCR Statistical Yearbook 2015, p. 4.

77 See UNHCR, Global Trends: Forced Displacement in 2016 (June 19, 2017), www.unhcr.org/ dach/wp-content/uploads/sites/27/2017/06/2016_Global_Trends_WEB-embargoed.pdf.

$7^{8}$ UNHCR, Global Action Plan to End Statelessness (2014), www.refworld.org/docid/545b47d64 .html.

79 See UNHCR, “ibelong," www.unhcr.org/ibelong/.

8o See UNHCR, “Sign the Open Letter," www.unhcr.org/ibelong/sign-the-open-letter/. 
improving birth registration, and providing training. ${ }^{81}$ What is more, UNHCR has also set itself further annual targets, including that 100,000 individuals will acquire nationality or have it confirmed by the end of $2020 .^{82}$

Furthermore, although UNHCR has improved its data collection, the significant gaps in its coverage and quality of information presented undermine its advocacy efforts. UNHCR has not yet arrived at a consistent position on the inclusion of those who do not neatly fall within its mandate. There is a lack of disaggregation in the figures presented, which leaves UNHCR's data open to misinterpretation. It remains unclear if those with indeterminate status are truly considered stateless for the purposes of estimation.

Until recently, UNHCR gave the impression of an agency that was driving forward its ambitions blind to the aforementioned substantive methodological considerations. Official publications from 2019 now qualify that the data presented are incomplete, and on its website, there is an apologetic note which explains that it compiles data on two categories: stateless persons who meet the Convention definition (de jure), and persons with undetermined nationality, but that over the past decade these and the de facto category "have sometimes been applied inconsistently in different UNHCR country operations for the annual statistical reporting process." ${ }{ }_{3}$

Despite these problems, the UNHCR continues to present as reliable the statistical information it has collected, which omits estimates from highly populated regions of the world where discrimination based on nationality, the denial of documents, and the refusal to accede to - and abide by - international legal instruments and standards are the norm. The same criticism could be leveled at UNHCR's most vocal advocates, which published simplistic accounts that reiterated the agency's claims and repeated its calculation errors, ${ }^{84}$ though eventually they too started to raise questions. ${ }^{85}$

\section{Operational Challenges and Methodological Solutions}

This account illustrates just how difficult it is for humanitarian agencies, including UNHCR, to establish accurate figures. It also records how institutional preferences

${ }^{81}$ In the 2019 High-Level Segment on Statelessness during the Executive Committee gathering held on October 7, 2019, UNHCR reported that 252 of these pledges were delivered by States, 70 by civil society organizations, and 38 by international and regional organizations. See UNHCR, "Results of the High Level Segment on Statelessness," www.unhcr.org/ibelong/ results-of-the-high-level-segment-on-statelessness/.

${ }^{82}$ UNHCR, “UNHCR in 2020," https://reporting.unhcr.org/sites/default/files/gazozo/pdf/Chapter_ Overview.pdf.

83 See UNHCR, "Measuring Forced Displacement and Statelessness," www.unhcr.org/refugeestatistics/methodology/.

${ }^{84} \mathrm{See}$ Institute on Statelessness and Inclusion, The World's Stateless, https://files.institutesi.org/ worldsstateless.pdf.

85 Institute on Statelessness and Inclusion, "Statelessness in Numbers: 2019 - An Overview and Analysis of Global Statistics,” https://files.institutesi.org/ISI_statistics_analysis_2019.pdf. 
may be formed. In the cases discussed, we note how statist and technocratic biases have privileged national sources as "reliable," even as some states have engaged in efforts to redefine membership based on exclusive understandings of nationality. Such biases are not new: As Dunlop recorded almost ten years ago, the use of resultsbased management tools favored states over other beneficiaries, above all those who fell under its protection mandate. ${ }^{86}$ In addition, UNHCR's tendency to limit reporting on statelessness to de jure stateless populations - until very recently may have encouraged a process of methodological revisionism where the numbers of stateless people in need of protection were rounded down. Narrowing legal definitions logically leads to undercounting.

As argued earlier, it is potentially a fallacious assumption that individuals and groups that may be experiencing persecution from a particular state and may have had their nationality withdrawn should then have their claims affirmed by the state in question. It is perverse to suggest that such states might be called upon to record the presence of these stateless people and remedy their situation. Even when states have grappled with the issues of statelessness and demonstrated a commitment to examine claims, a heavy evidentiary burden still falls on individual applicants. Even though statelessness determination procedures were introduced in the United Kingdom in 2013, additional rules have been designed that disadvantage applicants. In $2019^{87}$ and again in 2020, the UK Immigration Rules were amended to include further requirements, such as the obligation to obtain a residence permit in the United Kingdom. The new rules still require a stateless applicant to have "sought and failed to obtain or re-establish their nationality with the appropriate authorities of the relevant country." 88 As the case studies of the Kashmiri children and Teh record, seeking status on the basis of a claim to being stateless is far from straightforward.

How UNHCR identifies those under its statelessness mandate remains contentious. As recorded earlier, there was a tendency to take large numbers of people out of the category of statelessness by excluding de facto stateless individuals. Now, there is a shift to aggregate de jure and de facto stateless people as well as those with indeterminate nationality. While this might make reporting simpler, it does not inform our understanding of why these people are stateless and how their plight may be corrected.

There are many broader possible explanations for UNHCR's attachment to such practices, which complement Reichel's notion of normative path dependency

86 Dunlop, Indications of Progress.

${ }^{87}$ See House of Commons, "Statement of Changes in Immigration Rules" (October 24, 2019), https://assets.publishing.service.gov.uk/government/uploads/system/uploads/attachment_data/ file/841772/CCSoo1_CCS1019317048-001_Statement_of_changes_in_Immigration_Rules_ Text.pdf.

88 See "Immigration Rules Part 14: Stateless Persons" (June 4, 2020), www.gov.uk/guidance/ immigration-rules/immigration-rules-part-14-stateless-persons. 
discussed earlier. Sociologists have long sought to challenge the presentation of actors, including organizations, as rational and agentic; rather, they suggest that organizations operate in an environment constructed around social practices that give rise to institutional norms. One recurring theme is the notion of "institutional scripts." ${ }^{89}$ Drawing upon Berger and Luckmann's phenomenological approach, ${ }^{9 \circ}$ where the actor - be it an individual or organization - operates on a social stage and has a scripted identity that enacts a scripted action, for example, a role, Meyer argues that "actorhood" is also scripted by institutional structures. He claims that both actors (e.g., organizations) and actions (e.g., policies, decisions, innovations) have institutional scripts behind them: "The actor-action relation is a package, and as people and groups enter into particular forms of actorhood, the appropriate actions come along and are not usefully to be seen as choices and decisions." "Jist as people fall into roles, so too do organizations.

In this chapter, we might consider UNHCR's reliance on statistical measures, its quest for indicators, and the use of results-based management as part of an institutional script. As Sarfaty argues, institutions draw their legitimacy from international legal instruments that rely on indicators to operationalize global norms and assess compliance. Indicators drive agendas - "what gets measured, gets done." ${ }^{2}$ As UNHCR engaged in comprehensive management and structural reform, it followed the example of other UN agencies and turned to managerialist approaches that relied on the collection of measurable data to advance claims of greater accountability, efficiency, and effectiveness. One might argue that a restrictive understanding of UNHCR's 1951 mandate reduces the numbers of stateless people under its remit, and hence helps to demonstrate success and better positions the agency to meet its ambition of ending statelessness.

\section{RECOMMENDATIONS}

As the Conference of European Statisticians noted in 2008, UNHCR and its partners could improve the way they collect data on statelessness. There are some glimpses of progress, for example, in reporting on selected countries, where figures have been adjusted, as well as in recent conversations between UNHCR and critics who have presented compelling alternative methodologies, most notably the Center for Migration Studies (CMS). 93

89 J. W. Meyer, "World Society, Institutional Theories, and the Actor" (2010) 36 Annual Review of Sociology 1-20.

$9^{\circ}$ P. L. Berger and T. Luckmann, The Social Construction of Reality: A Treatise in the Sociology of Knowledge (Garden City, NY: Anchor Books, 2010).

${ }^{91}$ J. W. Meyer, "Reflections on Institutional Theories of Organizations," in R. Greenwood, C. Oliver, R. Suddaby, and K. Sahlin (eds.), The SAGE Handbook of Organizational Institutionalism (London: SAGE Publications Ltd, 2008), p. 792.

92 Sarfaty, "Regulating Through Numbers" at p. 588.

93 Kerwin et al., "Statelessness in the United States." 
Yet, to arrive at a better quality of data, the top-down approach of applying narrow legal definitions should be revisited. As noted earlier, most censuses rely on self-identification, while UNHCR's definition of who counts as a stateless person is determined by the definitions found in the 1954 Convention. In this context, the inclusion of questions on citizenship in national censuses is indicative of a broader problem. While capturing data on those who may be considered de jure stateless, the use of national censuses also offers an opportunity to clarify what is meant by "indeterminate nationality," and hence evidence of nationality and state recognition. Questions posed to respondents should, therefore, capture data on their access to rights, concomitant with definitions of citizenship. Although this approach takes us well beyond UNHCR's reach, it would nonetheless assist the agency to have more standardized definitions and to remove some of the exceptions as found in the small print of its official reports.

In terms of UNHCR's own reporting, as Kerwin et al. contend, the different ways in which statelessness arises require specific methodologies that cannot be applied across the board. ${ }^{94}$ For example, if stateless people are located in a region that has witnessed succession or defederation, then that may encourage an investigation of rates of naturalization among de jure stateless people and the incorporation of those data in subsequent estimates. One might reasonably start by investigating de jure population estimates at the point when new nationality legislation is introduced. Equally, in countries that have introduced new nationality reforms, as in Madagascar where women may now pass on nationality to their children, it would be appropriate to adjust figures. In this instance, official demographic information would record that, under stable conditions, the numbers of stateless people would decline as children reach the age of majority. When adjusting population estimates, it is important to consider the interplay of other factors. If, as Balaton-Chrimes et al. observe, deprivation of nationality reduces the quality of health, ${ }^{95}$ then this factor should be considered for its impact on life expectancy - though there are also conflicting studies that suggest limits to this approach. ${ }^{96}$

The relationship between migration and statelessness should also be interrogated on a country by country basis to assess the status of migrant populations whose nationality status may have lapsed during their time spent abroad and who may be at risk of statelessness. For example, Danish nationals born outside Denmark may lose their Danish nationality on attaining the age of twenty-two, unless they apply between the ages of twenty-one and twenty-two to retain it. ${ }^{97}$ Other countries similarly place restrictions on foreign-born nationals living abroad. Such an

94 Ibid.

95 S. Balaton-Chrimes, B. K. Blitz, M. Lynch, and R. W. D. Lakshman, The Cost of Statelessness: A Livelihoods Analysis (Washington, DC: U.S. Department of State, 2011).

${ }^{6}$ L. Liu and G. Singh, "Mortality Trends and Differentials by Nativity Status in the United States" (2018) 28 European Journal of Public Health 21,https://doi.org/10.1093/eurpub/ckyo47.008.

97 Ministry of Foreign Affairs of Denmark, "Danish Nationals Born Outside Denmark and the 22-Year Rule,” 2020, https://storbritannien.um.dk/en/travel-and-residence/family-and-legalmatters/dual-and-multiple-nationality/danish-nationals-born-abroad/. 
investigation requires contextual knowledge of the selected countries, the immigration histories of settled migrants, and up-to-date information on the country of origin of arriving migrants. It may require a mapping against the nationality laws of both countries of origin and destination for the selected migrant groups to determine their risk of losing nationality.

UNHCR could also take the bold step of affirming the status of certain groups as stateless persons, rather than bracket them off as people of "indeterminate nationality." This is not without precedent. Not only has UNHCR abandoned the use of some accepted categories, such as de facto stateless, but it has also created new ones. We note that while UNHCR recognizes that stateless people may also be refugees and should be included in their data on refugees, it has reported on more than one category and has equally created a formal category of stateless IDPs in the case of the Rohingya. ${ }^{8}$

The above recommendations may improve the ways in which UNHCR collects data. They may also help to advance the wider ambition of providing effective humanitarian protection and give greater meaning to its claims to support participation with beneficiaries, including stateless people. How UNHCR reports on those under its mandate has many knock-on effects, including cooperation with national governments and partner agencies that rely on their data, notably the International Organization for Migration and World Bank. Without accurate data on populations of concern for UNHCR, the task of identifying and allocating resources becomes considerably harder for them too.

\section{CONCLUSION}

When the international community addressed the plight of stateless people in the aftermath of the Second World War, statelessness was bolted onto the emerging refugee regime and only later emerged as an issue area in its own right. ${ }^{99}$ Since then, statelessness has crept up the agenda and is now recognized as a global problem. Although UNHCR has included stateless people in its reporting for more than a decade, it began doing so without established definitions and lately has underestimated the scale of the problem.

For social scientists, this conclusion may not be surprising. As an international agency, UNHCR relies on the interpretation of international law and on this basis has experimented with the establishment of operational definitions. These definitions are neither sufficiently inclusive nor precise to capture the reality of a world where hundreds of millions of people are on the move, many without recognized status, and where others may be locked in discriminatory systems unable to enjoy such levels of mobility.

The absence of accurate data reduces the chances that UNHCR will be able to measure the effectiveness of its work and achieve its targets. As UNHCR recognizes,

$9^{8}$ UNHCR, "Statelessness: An Analytical Framework".

99 Batchelor, "Stateless Persons." 
its own data are limited to under half the world's countries and to stateless people under its mandate. Hence, UNHCR's data are at best a rough projection of a much larger global problem.

UNHCR has argued that "the best way to address statelessness is to prevent it from occurring." ${ }^{100}$ This is undeniably true, but it is not a simple task. As Brennan argues, in her discussion of feminist approaches to understanding statelessness, the battle lines are not simply ineffective laws but rather the wide-ranging structures that permit hierarchies, privilege, and domination. ${ }^{101}$ As noted in this chapter, there are broader sociological explanations behind the use of narrow definitions and emphasis on statistical data and indicator-based frameworks that are found in many institutional scripts circulating among international organizations. ${ }^{102}$ Controversially, we might add that the persistence of such scripts is fostered by patterns of recruitment within UNHCR and partner NGOs - legal experts untrained in social scientific study who have not questioned the prevailing orthodoxy.

UNHCR could start by reviewing its own biases, including a top-down logic that drives demand for "results." Equally, rather than exclude categories of stateless persons that are harder to identify, such as those who may have indeterminate status, it could further investigate their claims and grant them status, as it has done with Rohingya IDPs. ${ }^{103}$ UNHCR and its partners would do well to constantly review the causes of statelessness, including the prospect of millions of people living in situations of protracted displacement as a result of the global crises mentioned, and use this information to inform their profiling and data collection. These recommendations require both greater contextual knowledge and familiarity with more sophisticated demographic methods. In this context, the creation of a Joint Data Center on Forced Displacement with the World Bank is encouraging, provided it includes stateless people within its remit and does not fall prey to the deficiencies of the aforementioned results-based approaches. ${ }^{104}$ If the aim is to end statelessness by 2024, then it is urgent UNHCR and its partners address their limitations.

${ }^{100}$ UNHCR, “Statelessness: An Analytical Framework," p. 7.

${ }^{101}$ D. Brennan, "Statelessness and the Feminist Toolbox: Another Man-Made Problem with a Feminist Solution?" (2019) 24 Tilburg Law Review 170-181.

${ }^{102}$ Merry, "Human Rights Monitoring."

${ }^{103}$ See UNHCR, Global Trends: Forced Displacement in 2018, Annex Table 1, p. 67, n.29 ("The figure of persons of concern under the statelessness mandate relates to stateless persons in Rakhine state and persons of undetermined nationality residing in other states in Myanmar. The figure of stateless persons in Rakhine state has been estimated on the basis of the 2014 census report and 2017 General Administration Department (GAD) of Ministry of Home Affairs (MoHA) data. This figure exceptionally includes stateless IDPs who are also of concern under the statelessness mandate. This approach will not be replicated in the database and in the Excel version of this table and, therefore, figures may differ.").

${ }^{104}$ See Strategic Advisory Council, Strategy for the Joint Data Center on Forced Displacement 2021-2023: Zero Draft. 